\title{
Prevalence of celiac disease and celiac autoimmunity in the Toba native Amerindian community of Argentina
}

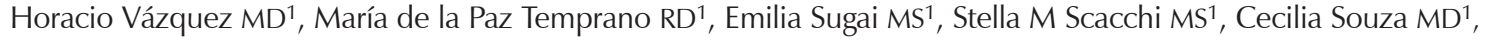

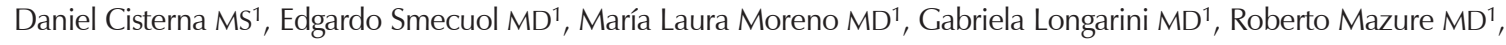

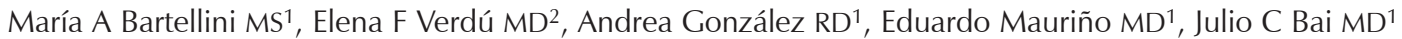

H Vázquez, M de la Paz Temprano, E Sugai, et al. Prevalence of celiac disease and celiac autoimmunity in the Toba native Amerindian community of Argentina. Can J Gastroenterol Hepatol 2015;29(8):431-434.

BACKGROUND: Celiac disease (CD) is mostly recognized among subjects with a Caucasian ethnic ancestry. No studies have explored conditions predisposing Amerindians to CD.

OBJECTIVE: To prospectively assess environmental, genetic and serological conditions associated with CD among members of the Toba native population attending a multidisciplinary sanitary mission.

METHODS: An expert nutritionist determined daily gluten intake using an established questionnaire. Gene typing for the human leukocyte antigen (HLA) class II alleles was performed on DNA extracted from peripheral blood (HLA DQ2/DQ8 haplotype). Serum antibodies were immunoglobulin ( $\mathrm{Ig}$ ) A tissue transglutaminase ( $\mathrm{tTG}$ ) and the composite deamidated gliadin peptides/tTG Screen test. Positive cases were tested for IgA endomysial antibodies.

RESULTS: A total of 144 subjects (55\% female) were screened. The estimated mean gluten consumption was $43 \mathrm{~g} /$ day (range $3 \mathrm{~g} /$ day to $185 \mathrm{~g} /$ day). Genetic typing showed that 73 of 144 (50.7\%) subjects had alleles associated with CD; 69 (94.5\%) of these subjects had alleles for HLA DQ8 and four had DQ2 (5.5\%). Four and six subjects had antibody concentrations above the cut-off established by the authors' laboratory ( $>3$ times the upper limit of normal) for IgA tTG and deamidated gliadin peptides/tTG screen, respectively. Four of these had concomitant positivity for both assays and endomysial antibodies were positive in three subjects who also presented a predisposing haplotype.

CONCLUSION: The present study was the first to detect CD in Amerindians. The native Toba ethnic population has very high daily gluten consumption and a predisposing genetic background. We detected subjects with persistent CD autoimmunity and, at least, three of them fulfilled serological criteria for CD diagnosis.

Key Words: Amerindians; Celiac autoimmunity; Celiac disease; Genetic predisposition; Gluten consumption; Tissue transglutaminase (tTG)

\section{La prévalence de maladie coliaque et d'auto- immunité cœliaque dans la communauté amérindienne toba d'Argentine}

\begin{abstract}
HISTORIQUE : Ce sont surtout des Blancs qui sont atteints de la maladie cœliaque (MC). Aucune étude n'a porté sur les troubles prédisposant les Amérindiens à la MC.

OBJECTIF : Effectuer une évaluation prospective des troubles environnementaux, génétiques et sérologiques associés à la $\mathrm{MC}$ chez les membres du peuple amérindien toba qui fréquentaitent une mission sanitaire multidisciplinaire.

MÉTHODOLOGIE : Un expert en nutrition a déterminé la consommation quotidienne de gluten au moyen d'un questionnaire déterminé. Les chercheurs ont procédé au génotypage des allèles de classe II de l'antigène d'histocompatibilité humain (HLA) de l'ADN extrait du sang périphérique (haplotype HLA DQ2 ou DQ8). Les anticorps sériques étaient la transglutaminase tissulaire (tTG) de l'immunoglobuline (Ig) A et le test de dépistage composite des peptides de gliadine déamidés/tTG. Les cas positifs ont été testés pour dépister les anticorps antiendomysium de l'IgA.
\end{abstract}

RÉSULTATS : Au total, 144 sujets (55\% de femmes) ont participé au dépistage. Leur consommation estimative moyenne de gluten était de $43 \mathrm{~g} /$ jour (plage de $3 \mathrm{~g} /$ jour à $185 \mathrm{~g} /$ jour). Le génotypage a révélé que 73 des 144 sujets $(50,7 \%)$ avaient des allèles associés à la MC, 69 d'entre eux (94,5 \%), des allèles HLA DQ8 et quatre, des allèles DQ2 (5,5\%). Quatre et six sujets présentaient des concentrations d'anticorps supérieures aux seuils établis au laboratoire des auteurs (plus de trois fois le seuil supérieur normal) pour dépister les tTG IgA et les peptides de gliadine déamidés/tTG, respectivement. Quatre d'entre eux étaient également positifs aux deux tests, et les anticorps anti-endomysium étaient positifs chez trois sujets qui présentaient également un haplotype prédisposant.

CONCLUSION : La présente étude a été la première à déceler des cas de $\mathrm{MC}$ chez les Amérindiens. Le peuple amérindien toba consomme énormément de gluten au quotidien et présente des antécédents génétiques prédisposants. Les auteurs ont décelé des sujets présentant une auto-immunité persistante à la $\mathrm{MC}$ et au moins trois d'entre eux satisfaisaient les critères sérologiques du diagnostic de $\mathrm{MC}$.

in Northeastern Argentina. This community experiences highly precarious social, economic, sanitary and educational conditions (5). In recent years, they have undergone a drastic change in dietary habits, with wheat replacing their ancestral food sources (6). This has mainly occurred as a consequence of governmental food aid programs aimed at improving nutritional conditions in the community. CD can only occur in individuals with certain class II human leukocyte antigen (HLA) molecules - namely, HLA DQ2 and/or DQ8. In this context, scarce information exists about the prevalence of HLA DQ2 and DQ8, and of CD in native South Americans (7).
(1). The disease has been traditionally recognized among Caucasians; the estimated prevalence in the Western world is approximately $1 \%$ (2). CD is increasingly recognized in the Asian-Pacific region (3). In Latin America, there is a variable proportion of the population with European ancestry, with native communities having a diverse degree of mix with European colonizers (4).

The native Toba ethnic population comprises $>60,000$ individuals living with a cluster distribution in a forest named 'The Impenetrable'

${ }^{1}$ Small Bowel Section, Department of Medicine, Hospital de Gastroenterología C Bonorino Udaondo. Buenos Aires, Argentina; ${ }^{2}$ Farncombe Family Digestive Health Research Institute, McMaster University, Hamilton, Ontario

Correspondence: Dr Elena Verdú, Farncombe Family Digestive Health Research Institute, McMaster University, 1200 Main Street West, HSC 3N5C,

Hamilton, Ontario L8N 325. Telephone 905-525-9140 ext 22212, fax 905-570-8962, e-mail verdue@mcmaster.ca

Received for publication February 17, 2015. Accepted March 7, 2015 


\begin{tabular}{|c|c|c|c|}
\hline Characteristic & $\begin{array}{c}\text { Overall } \\
\text { population }\end{array}$ & Children & Adults \\
\hline Subjects, $n$ & 144 & 40 & 104 \\
\hline Age, years, median (range) & $30(3-79)$ & $8(3-17)$ & $36(19-79)$ \\
\hline Sex, female/male, $\mathrm{n} / \mathrm{n}$ & $80 / 64$ & $20 / 20$ & $60 / 44$ \\
\hline Body weight, $\mathrm{kg}$, mean \pm SEM & $63.5 \pm 1.9$ & $38.1 \pm 3.1$ & $73.3 \pm 1.5$ \\
\hline $\mathrm{BMI}, \mathrm{kg} / \mathrm{m}^{2}$, mean $\pm \mathrm{SEM}$ & $26.1 \pm 0.5$ & $28.5 \pm 0.5$ & $19.8 \pm 0.8$ \\
\hline Underweight, n (\%) & $9(6)$ & $5(13)$ & $4(4)$ \\
\hline Normal weight, $\mathrm{n}(\%)$ & $44(31)$ & $16(37)$ & $28(27)$ \\
\hline Overweight, n (\%)* & $91(63)$ & $19(50)$ & $72(69)$ \\
\hline $\begin{array}{l}\text { Gluten consumption, g/day, } \\
\text { mean } \pm \text { SEM }\end{array}$ & $43.1(2.7)$ & $27.5(4.9)$ & $48.9(3.1)$ \\
\hline
\end{tabular}

*Overweight for children was considered to be weight above the $97 \%$ percentile

Accordingly, we explored CD risk factors in members of the Toba community attending a multidisciplinary sanitary mission. Our specific aims were to estimate the consumption of gluten; determine the associated celiac genetic risk (ie, HLA DQ2/DQ8); and screen the population for CD.

\begin{abstract}
METHODS
Definitions and overall study design

The present prospective population-based study has two major end points: diagnosis of $\mathrm{CD}$ autoimmunity and serological diagnosis of CD. $\mathrm{CD}$ autoimmunity was defined as two positive serological tests ( $\geq 3$ times the upper limit of normal) in samples taken four months apart. Serological CD diagnosis was established in patients with positive ELISA serology and positive immunoglobulin (Ig)A endomysial antibodies (EmA). The study was approved by the Ethics and Scientific Boards of the C. Bonorino Udaondo Gastroenterology Hospital of Buenos Aires, Argentina. Written or expressed consent was obtained from enrolled subjects in the presence of the community leaders and/or their parents.
\end{abstract}

\section{Study participants}

From March 2013 through March 2014, four multidisciplinary missions by the same team were performed in the Toba population living in 'The Impenetrable', in the province of Chaco, Argentina. All subjects attending the health mission and fulfilling inclusion criteria were invited to participate in the study by a physician in the presence of the community leader. Individuals $<3$ years of age or having a previous diagnosis of $\mathrm{CD}$ were excluded, as well as those refusing blood sampling for cultural reasons. A full clinical history, physical examination and blood samples were obtained.

\section{Nutritional analysis and gluten consumption}

A nutritionist-expert in CD interviewed subjects at enrollment. Gluten consumption was estimated using a food frequency intake questionnaire (11) and compared with data obtained from a $48 \mathrm{~h}$ food recall recorded by the same nutritionist. The food frequency intake estimates the frequency of consumed foods during a specific period of time and identifies all foods containing wheat, rye and barley; the gluten content was calculated following previously described methods, taking into account only known gluten-containing products (11-14).

\section{CD-specific serology}

Serum samples obtained were kept frozen $\left(-20^{\circ} \mathrm{C}\right)$ until analysis at Hospital de Gastroenterología C. Bonorino Udaondo. Serology tests included IgA antibodies to tissue transglutaminase (tTG) using ELISA (Quanta Lite h-tTG IgA, Inova Diagnostic Inc, USA), and the dual detection of IgA and IgG isotypes of antibodies to deamidated gliadin peptide (DGP) and tTG in a single assay (DGP/tTG Screen; Quanta
Lite h-tTG/DGP Screen, Inova Diagnostic Inc). The cut-off value specified by the manufacturer for the ELISA assays were $20 \mathrm{U} / \mathrm{mL}$ but the cut-off used in the present study was based on that estimated by the authors in an earlier study ( $>3$ times the upper limit of normal [60 U/mL for both tests]) (15). Positive ELISA tests were analyzed for IgA endomysial antibodies (IgA EmA) using immunofluorescence on primate esophagus substrate (dilution 1:5). Positive samples were retested after four months during a new visit to the mission to rule out transient positivity.

\section{CD-related HLA genotyping}

CD specific gene typing for the detection of HLA class II alleles was performed on DNA from a drop of whole blood obtained from the fingertip and collected on a paper filter card (Whatman 903 FTA, Whatman, USA). Samples were stored at room temperature and analyzed at the BioDiagene laboratory (Italy). A DQ-CD Typing Plus kit (BioDiagene, Italy) was used for the identification of HLA class II alleles: DQA $1 * 0201, * 03, * 05, \mathrm{DQB} 1 * 02, * 0301 / 04$ and $* 0302$.

\section{Statistical analysis}

Population data are reported as percentage, median and range or mean \pm SEM, as appropriate. The Mann-Whitney test for independent samples was used for comparison of patients with and without CD autoimmunity.

\section{Study population}

\section{RESULTS}

A total of 144 subjects (55\% female) were enrolled. Patients' characteristics are summarized in Table 1. Briefly, mean body mass index was above the range of normal weight and most subjects had normal weight or were overweight. Mean biochemical parameters were within normal range (data not shown). No IgA-deficient cases were detected. Genetic typing showed that 73 of $144(50.7 \%)$ subjects had alleles associated with CD; 69 of these subjects (94.5\%) had alleles for HLA DQ8 and 4 had DQ2 (5.5\%).

\section{Gluten consumption}

The estimated mean gluten consumption for all enrolled subjects was almost double of that assessed for populations living in urban areas of Argentina (unpublished data) and in other parts of the world (16) (Table 1).

\section{Identification of subjects with $\mathrm{CD}$ and persistent celiac autoimmunity}

Two adults (both female, 23 and 38 years of age) and one child (male, 12 years of age) fulfilled serological criteria for CD (Table 2). One additional child (female) was excluded from enrollment due to previous CD diagnosis. From the newly CD diagnosed patients, one adult female had normal body mass index, the other was overweight and the child was obese. The patients were asymptomatic and biochemical parameters were normal (Table 3). High gluten consumption was detected in two of the three $(114 \mathrm{~g} /$ day and $29 \mathrm{~g} /$ day for the adults, and $91 \mathrm{~g} /$ day for the child). The child was HLA DQ2+, and both adults were positive for HLA DQ8 (Table 2).

Three additional subjects (two HLA-DQ8+) had serum concentrations of CD antibodies above normal. In three, DGP/tTG was positive while both DGP/tTG and IgA tTG were positive in two. Repeat serology four months apart was positive in all three and, thus, they were considered to have persistent CD autoimmunity. Daily gluten intake was normal in two of these subjects, and high in one (Table 2).

\section{DISCUSSION}

We prospectively explored the consumption of gluten by the apparently healthy native Toba community, the frequency of HLA $\mathrm{CD}$-predisposing genotypes, and the prevalence of CD autoimmunity and serological evidence of the disorder. The present study revealed a very high consumption of gluten, almost twofold higher than that of individuals of European ancestry living in urban areas of Argentina 


\begin{tabular}{|c|c|c|c|c|c|}
\hline \multirow{2}{*}{\multicolumn{3}{|c|}{\begin{tabular}{l} 
TABLE 2 \\
Individual estimation of gluten \\
human leukocyte antigen (HLA \\
status in patients considered to \\
autoimmunity* or celiac diseas \\
\multicolumn{1}{c}{ Gluten } \\
Subject: age consump- \\
(years), sex tion, g/day HLA typing
\end{tabular}}} & \multicolumn{3}{|c|}{ DGP/tTG } \\
\hline & & & $\begin{array}{c}\operatorname{IgA} \mathrm{tTG} \\
\mathrm{U} / \mathrm{mL}\end{array}$ & $\begin{array}{c}\text { Screen test, } \\
\mathrm{U} / \mathrm{mL}\end{array}$ & $\operatorname{Ig} A$ EmA \\
\hline 1: 33, male & 136 & $\begin{array}{l}\text { DR4-DQ8/ } \\
\text { DQ7 }\end{array}$ & $12 / 9$ & $80 / 101$ & $-\mathrm{ve} /-\mathrm{ve}$ \\
\hline 2: 72, male & 26 & DQ7 & $37 / 32$ & $80 / 101$ & $-v e /-v e$ \\
\hline 3: 38, male & 22 & DQ8 & $120 / 63$ & $109 / 77$ & $-v e /-v e$ \\
\hline $4: 12$, male & 91 & $\begin{array}{l}\text { DR7-DQ2/ } \\
\text { DQ7 }\end{array}$ & $>200 />200$ & $>200 />200$ & $+v e / N D$ \\
\hline 5: 38 , female & 114 & $\begin{array}{l}\text { DR4-DQ8/ } \\
\text { DQ7 }\end{array}$ & $131 / \mathrm{ND}$ & 100/ND & $+v e / N D$ \\
\hline $6: 23$, female & 29 & DQ8 & $>200 / N D$ & 60/ND & $+v e / N D$ \\
\hline
\end{tabular}

${ }^{*}$ Patients 1, 2 and 3 ; 'Patients 4, 5 and 6 . Serum concentration of ELISA tests (immunoglobulin A [lgA], tissue transglutaminase [tTG] and deamidated gliadin peptides [DGP]/tTG Screen was re-tested in patients four months after the first positive result. Data above are presented as test 1/test 2 results. EmA Endomysial antibody; ND Not determined

and in other parts of the world (16). This alimentary change was the product of a political decision implemented almost 30 years ago to improve alarming nutritional deficits in this population. The initial aim of the alimentary support appears to have achieved relative success because anthropometric evaluations revealed few underweight subjects and normal biochemical parameters. An unintentional consequence of such important alimentary intervention was that $50 \%$ and $70 \%$ of children and adults, respectively, were overweight or obese at the time of the study. The quality of food support, consisting mainly of wheat, may have played a role in this outcome.

Similar to native populations in Brazil and Chile (17), our study showed that only $3 \%$ of subjects had the HLA DQ2 alleles (prevalent in European populations), while 48\% had the DQ8. This contrasts with the increased HLA-DQ2 allele frequency detected in Asia with high CD prevalence, as demonstrated in several recent studies $(17-20)$.

A significant observation in the present study was the detection of CD autoimmunity in six subjects. Three of these subjects had concomitant positivity in all tests and, therefore, qualified for CD diagnosis. The patients were asymptomatic, did not exhibit weight loss and gluten consumption was very high in two of the cases. The results raise concerns about CD risk in the Toba population and its association with the quality of food aid programs targeted at them.

The present small study was based on serological prevalence due, in part, to some cultural resistance to the implementation of the screening program and to the difficulty of implementing endoscopy assessment in this setting. However, according to our experience and those of others, a positive IgA EmA test is almost absolutely predictive of CD enteropathy.

\section{CONCLUSION}

The Toba population has environmental and genetic risk factors for the development of CD. The present study detected a very high consumption of gluten as the result of government food aid programs largely based on wheat products. The genetic background was dominated by alleles codifying for DQ8 antigen. Three patients in the present study fulfilled criteria for $\mathrm{CD}$ and three others for persistent $\mathrm{CD}$. One additional CD case had previously been identified in this community. These results raise important questions regarding the food quality in aid programs that should include a variety of non-gluten-containing grains and should prompt CD screening in these native populations.

\section{TABLE 3}

Demographic and some clinical characteristics of the three patients with serological diagnosis of celiac disease

\begin{tabular}{lccc}
\hline Characteristic & Patient 1 & Patient 2 & Patient 3 \\
\hline Age, years & 12 & 38 & 23 \\
Sex & Male & Female & Female \\
Clinical categorization* & Asymptomatic & Asymptomatic & Asymptomatic \\
Body mass index, kg/m² & 25.7 & 26.6 & 23.8 \\
Gluten consumption, g/day & 91 & 114 & 29 \\
\hline
\end{tabular}

*Clinical categorization was performed according to the Oslo nomenclature

AUTHORSHIP STATEMENT: All authors approved the final version of the article, including the authorship list. Horacio Vázquez: research design, collection of patients, analysis of results. María de la Paz Temprano: acquisition of nutritional and alimentary data. Emilia Sugai: serological testing. Stella M Scacchi: acquisition of sera and processing, clinical laboratory testing. Cecilia Souza: acquisition of data in the pediatric population. Daniel Cisterna: genetic samples. Edgardo Smecuol: research design. María Laura Moreno: analysis of data. Gabriela Longarini: analysis of data. Roberto Mazure: research design. María A Bartellini: genetic samples. Elena F Verdú: drafted the manuscript and revised it critically. Andrea González: analysis of nutritional and alimentary information. Eduardo Mauriño: study design, analysis of results and critical review of the draft. Julio C Bai: study design, analysis of results, drafted the final manuscript, guarantor of the article.

ACKNOWLEDGEMENTS: The authors thank Dr Sonia Kupfer (University of Chicago, Chicago, Illinois) for scientific discussions and critical review regarding the genetic determinations and interpretations of the current study. They also thank the Fundación Pequeños Gestos Grandes Logros, all members of the multidisciplinary sanitary missions, Inova Diagnostic Inc (USA) for generously providing kits for serology, and BioDiagene Laboratory (Italy) for generously performing CD genetic typing analyses free of charge.

FUNDING SUPPORT: The present study was partially funded by the Consejo de Investigación, MSAL, Buenos Aires City Government and the Asociación para el Estudio de Enfermedades del Intestino (AEDEI). Source for salary support of researchers is provided by the Buenos Aires City Government as part of their research duties. EFV holds a Canada Research Chair and is funded by CIHR MOP 123282.

\section{REFERENCES}

1. Ludvigsson JF, Leffler DA, Bai JC, et al. The Oslo definitions for coeliac disease and related terms. Gut 2013;62:43-52.

2. Bai JC, Fried M, Corazza GR, et al. World Gastroenterology Organization global guidelines on celiac disease. Clin Gastroenterol 2013;47:121-6.

3. Makharia GK, Mulder CJ, Goh KL, et al. Issues associated with the emergence of coeliac disease in the Asia-Pacific region: A working party report of the World Gastroenterology Organization and the Asian Pacific Association of Gastroenterology. World Gastroenterology Organization-Asia Pacific Association of Gastroenterology Working Party on Celiac Disease. J Gastroenterol Hepatol 2014;29:666-77.

4. Pereyra MA, Ortiz-Agostinho CL, Nishitokukado I, et al. Prevalence of celiac disease in an urban area of Brazil with predominantly European ancestry. World J Gastroenterol 2006;12:6546-50.

5. Martinez G. Pluralismo médico y etnomedicina entre los Tobas (Qom) del río Bermejito (Chaco, Argentina). Desafíos y aportes para una gestión intercultural de la salud en el Impenetrable Chaqueño. Revista del Museo de Antropología 2011;4:195-210.

6. Bernio JC. Conquest by chainsaw <www.dandc.eu/en/article/ logging-subtropical-dry-forest-deprives-indigenous-people-argentinatheir-livelihood> (Accessed September 24, 2013).

7. Ramos da Rosa Utiyama S, Coelho Ribas JL, Mitsunori Nisihara R, et al. Celiac disease in native Indians from Brazil: A clinical and epidemiological survey. N Am J Med Sci 2010;2:138-42. 
8. Peschken CA, Esdaile JM. Systemic lupus erythematosus in North American Indians: A population based study. J Rheumatol 2000;27:1884-91.

9. Houghton KM, Page J, Cabral DA, et al. Systemic lupus erythematosus in the pediatric North American Native population of British Columbia. J Rheumatol 2006;33:161-3.

10. Ferucci ED, Templin DW, Lanier AP. Rheumatoid arthritis in American Indians and Alaska Natives: A review of the literature. Semin Arthritis Rheum 2005;34:662-7.

11. Overbeek FM, Uil-DietermanI G, MolI W, et al. The daily gluten intake in relatives of patients with coeliac disease compared with that of the general Dutch population. Eur J Gastroenterol Hepatol 1997;9:1097-9.

12. Levingstone MB, Prentice AM, Strain JJ. Accuracy of weighed dietary records in studies of diet and health. Br Med J 1900;300:708-12.

13. Hopman EG, Pruijn R, Tabben EH, et al. Food questionnaire for the assessment of gluten intake by children 1 to 4 years old. J Pediatr Gastroenterol Nutr 2012;54:791-6.

14. Ministerio de Salud. SARA: Sistema de Análisis y Registro de Alimentos. Consulta de Composición Química de los Alimentos. $<$ http://datos.dinami.gov.ar/produccion/sara/> (Accessed August 12, 2013).
15. Sugai E, Moreno ML, Hwang HJ, et al. Celiac disease serology in patients with different pretest probabilities: Is biopsy avoidable? World J Gastroenterol 2010;16:3144-52.

16. Lionetti E, Catassi C. Co-localization of gluten consumption and HLA-DQ2 and-DQ8 genotypes, a clue to the history of celiac disease. Dig Liv Dis 2014;46:1057-63.

17. Parada A, Araya M, Pérez-Bravo F, et al. Amerindian mtDNA haplogroups and celiac disease risk HLA haplotypes in mixed-blood Latin American patients. J Pediatr Gastroenterol Nutr 2011;53:429-34.

18. Catassi C, Doloretta Maccis M, Ratsch IM, et al. The distribution of DQ genes in the Saharawi population provides only a partial explanation for the high CD prevalence. Tissue Antigens 2001;58:402-6.

19. Shanmugalakshmi S, Balakrishnan K, Manoharan K, et al. HLA-DRB1*, -DQB1* in Piramalai Kallars and Yadhavas, two Dravidian-speaking castes of Tamil Nadu, South India. Tissue Antigens 2003;61:451-64.

20. Yuan J, Gao J, Li X, et al. The tip of the "celiac iceberg" in China: A systematic review and meta-analysis. PLoS One 2013;8:e81151. 


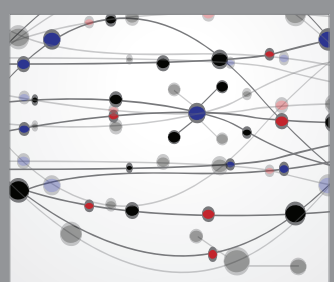

The Scientific World Journal
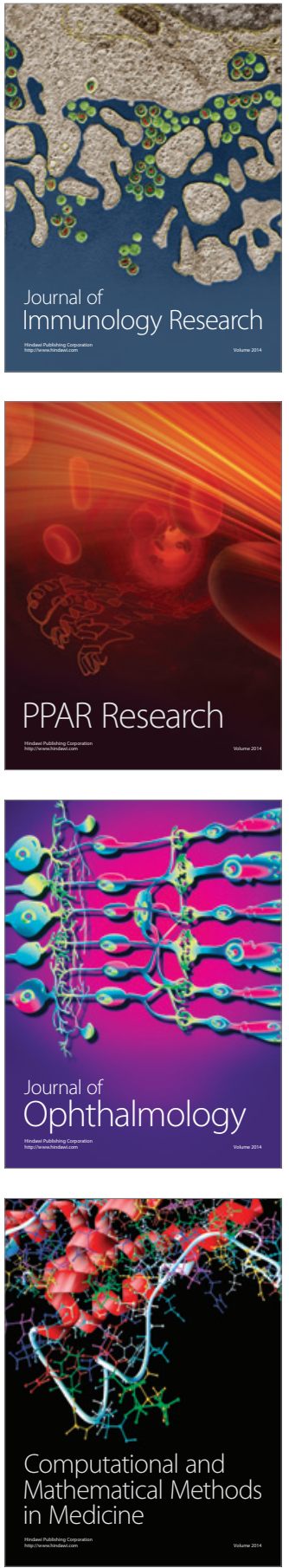

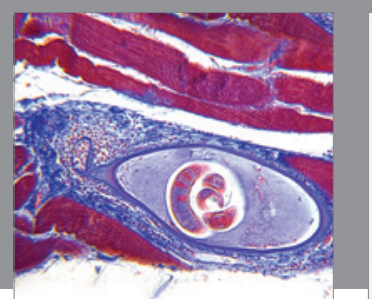

Gastroenterology Research and Practice

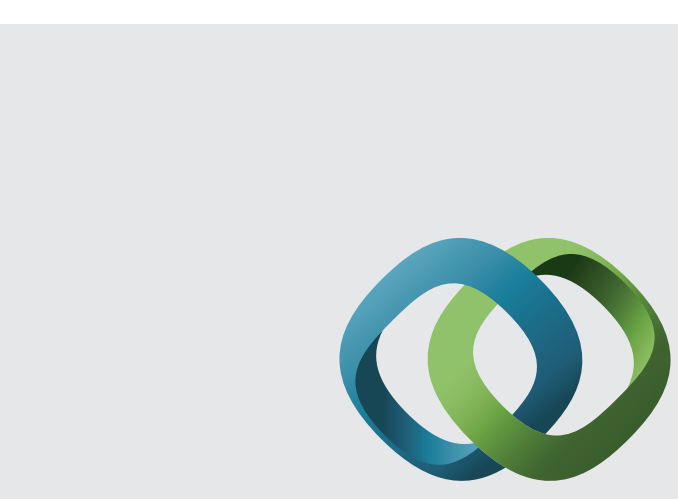

\section{Hindawi}

Submit your manuscripts at

http://www.hindawi.com
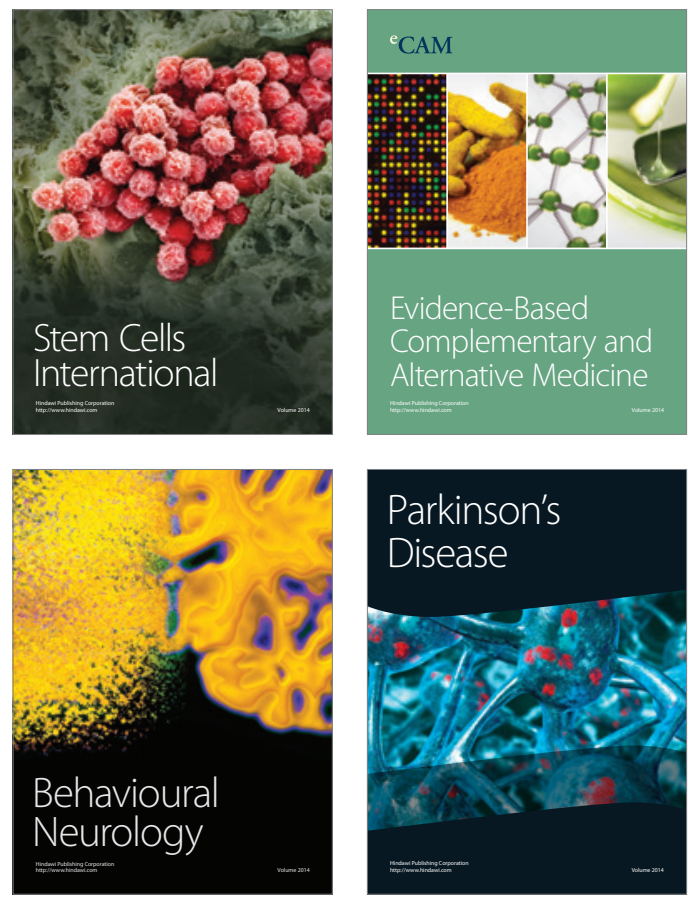
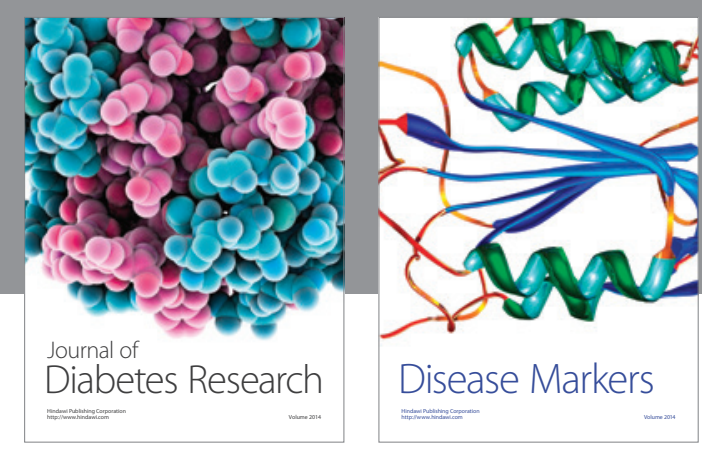

Disease Markers
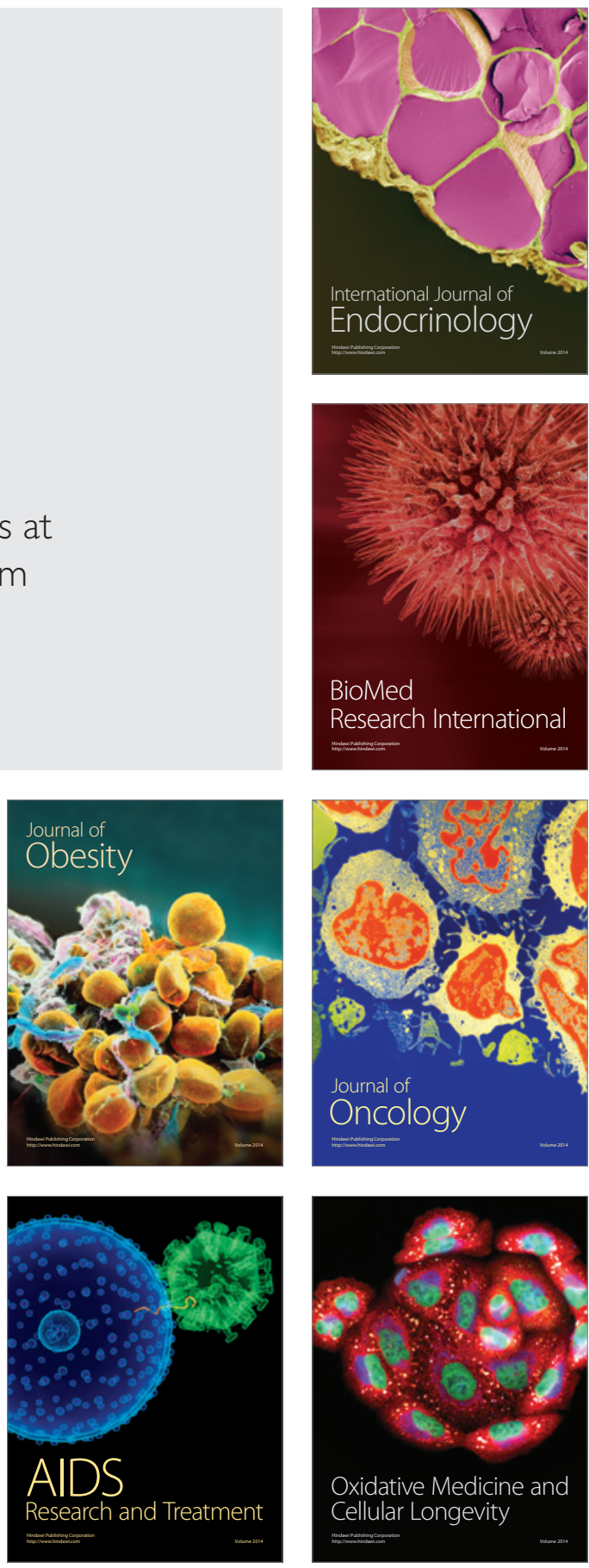